\title{
Prevention of TLR9 Pathway in Warm Ischemia in Porcine Donor Liver after Cardiac Death
}

\author{
Zigong Shao ${ }^{a}$ Baoping Jiao ${ }^{b}$ Dehui Yia Tingting Liu ${ }^{a}$ Qi Pan ${ }^{a}$ Ying Cheng $^{a}$ \\ Hao Liua \\ aDepartment of General Surgery, the First Hospital of China Medical University, Shenyang, ${ }^{\text {bDepartment }}$ \\ of General Surgery, the First Hospital of Liaoning Medical University, Jinzhou, China
}

\section{Key Words}

Liver transplant $\bullet$ Ischemia $\cdot$ Toll-like receptor $•$ Signal transduction

\begin{abstract}
Objective: To investigate effect of warm ischemia after cardiac death on activation of TLR9 pathway in porcine liver. Methods: Donor of cardiac death (DCD) model was established with Duroc, Landrace, Large White crossbred pigs. Liver tissues from the animals were harvested at $0,5,10,15,25$ and 30 minutes after warm ischemia for analysis of expression of TLR9, IRF7, IFN- $\beta$, and TNF- $\alpha$ at mRNA and protein levels by real-time PCR and western blot, respectively, and for assessment of NF-KB/DNA binding activity by western blot detection of p65 protein. Results: Ischemia induced TLR9, IRF7, IFN- $\beta$, and TNF- $\alpha$ expression at both mRNA and protein levels in an ischemic time dependent manner. Among them, expression of TNF- $\alpha$ and IFN- $\beta$ was induced later than TLR9 and IRF7 did. Ischemia also enhanced NF-KB binding to DNA in the DCD liver tissue. Pretreatment with iCpG specifically blocked activation of TLR9 pathway triggered by ischemia in liver and protected the animals from ischemia-caused liver tissue damage. Conclusion: Warm ischemia activates TLR9 pathways in the porcine liver tissue. Blocking TLR9 pathway could offer protection from ischemia-caused liver tissue in DCD liver transplantation.

\section{Introduction}

Warm ischemia injury is closely related to postoperative complications and prognosis in liver transplantation [1], which can be divided into ischemia phase and reperfusion injury phase [2]. During the pathological process of warm ischemia injury, damage mainly occurs in the reperfusion phase [3]. Interruption of the source of oxygen and nutrients and accumulation of metabolites in the warm ischemia phase will inevitably lead to dysfunction 


\section{Cellular Physiology Cell Physiol Biochem 2017;41:1547-1554 \\ \begin{tabular}{l|l|l} 
and Biochemistry $10.1159 / 000470820$ & $\begin{array}{l}\text { Do } 2017 \text { The Author(s). Published by S. Karger AG, Basel } \\
\text { www.karger.com/cpb }\end{array}$ \\
\hline
\end{tabular} \\ Shao et al.: TLR9 Pathway in Warm Ischemia}

of cells and subcellular organs, such as mitochondrial dysfunction, impaired membrane function, etc [4], while breakdown products from dead cells causes damage to Kupffer cells, neutrophil and activation of platelet, which results in consequent release of large amounts of proinflammatory cytokines, such as TNF- $\alpha$, IL-1 $\beta$, IL-6, IL-10, etc. It is known that inflammatory cytokines released from the dead cells in the liver cause cell damage individually or synergistically $[5,6]$. For example, TNF- $\alpha$ can directly lead to sinusoidal endothelial cell swelling; and cause liver microcirculation barrier by mediating interaction between neutrophils and sinusoidal endothelial cells, which in turn aggravates liver ischemia and hypoxia [1]. Apoptosis and oxidative stress were reported to play important pathological roles as well during the reperfusion injury. The anit-inflammatory, anti-apoptosis, and antioxidative stress activities of propofol, sevoflurane, or delta-9-tetrahydrocannabinol (a kind of cannabinoid agonist) could protect effectively the reperfusion-induced hepatic injury [6, 7]. In addition, protein tyrosine phosphatase receptor-type 0 (PTPRO) may play a critical role because overexpression of PTPRO strongly downregulates both clinical and experimental liver fibrosis by affecting PDGF signaling [8].

The most prominent changes in liver tissue of warm ischemia are inflammation of hepatocytes, but the underlying mechanisms are unclear so far. Studies have found that Toll like receptors (TLRs), an important component of the innate immune system can mediate ischemic injury [1]. Among the 13 TLRs, TLR9 is expressed on dendritic cells, B cells and macrophages and other immune cells [3]. It can be activated by either pathogen ligands or DNA fragments produced after tissue damage [9]. TLR9 is initially localized within the cytoplasm endoplasmic reticulum, transported to lysosomes by virtue of the membrane protein NC9381, then binds to CpG DNA and recruit the adapter molecule MyD88 complex to form TLR9 complex (TLR9-MyD88- IRAK4-TRAF6) [10]. IRAK4 in the complex phosphorylates IRAKl, and activates transcription factor NFKB (nuclear factor kappa B) or IRF7 pathway to induce production of pro-inflammatory cytokines such as TNF- $\alpha$ and IFN- $\beta$ [3].

Kupffer cells, liver dendritic cells, NK cells and hepatic stellate cells all express TLR9 [11]. In addition, TLR9 down-regulates the expression of inflammatory cytokines including TNF- $\alpha$ and IL- 6 and diminishes ischemia-reperfusion induced hepatic injury in mice [1]. However, the exact underlying mechanisms are unknown. Herein we reported that warm ischemia activated TLR9 signaling pathways via TNF- $\alpha$ and IFN- $\beta$ molecules in a porcine liver transplant DCD (donor after cardiac death) model, and prevention of the TLR9 pathway by iCpG provided protection of hepatocytes from ischemia-reperfusion injury.

\section{Materials and Methods}

\section{Animals}

Experimental pigs with balanced gender (Duroc, Landrace, Large White crossbred pigs, provided by the Shenyang Agricultural University), weighing $25 \sim 30 \mathrm{~kg}$, were bred following regulations of animal welfares.

\section{Establishment of DCD model and collection of samples}

Prior to surgery, the animals were fasted for 24 hours. One hour prior to surgery, the animals were intravenously injected with $0.1 \mathrm{ml} / \mathrm{kg}$ of TRL9 inhibitor, i.e., inhibitory cytosine-guanosine dinucleotide (ODN2088, Invivogen), or intravenously injected with same amount of negative control for inhibitory oligonucleotide for murine specific CpGs (ODN 2088 Control, Invivogen). After anesthesia, overdose of muscle relaxants was given intravenously for making class 3 Maastricht DCD model by way of "asphyxiation" method $[12,13]$. Briefly, after dissection of the first hepatic porta, the common bile duct was resected on the upper edge of duodenal bulb, followed by dissection of hepatic artery and portal vein from their celiac artery and superior mesenteric confluence, respectively, upward to their entering into the liver. After sampling of abdominal aorta with $40 \mathrm{ml}$ of blood for baseline data, intravenous pancuronium at 60-100 $\mu \mathrm{g} / \mathrm{kg}$ was injected, with the ventilator stopped and immediate intravenous heparin at $3 \mathrm{mg} / \mathrm{kg}$ ). After meeting the 
cardiac death criteria [14], the animals were observed for 10 minutes. Then the ventilator was removed and perfusion of abdominal aorta with Ringer's lactate solution and gravity perfusion of portal vein with 1000 $\mathrm{ml}$ of $4{ }^{\circ} \mathrm{C} \mathrm{UW}$ solution at height of 1 meter was performed. After the biliary tree rinsed with $20 \mathrm{ml}$ of $4{ }^{\circ} \mathrm{C}$ saline, the liver was removed when it became homogenously white-yellow on surface and cold, and placed in $4^{\circ} \mathrm{C}$ UW preservation solution for further trimming.

Warm ischemia time was defined as the period from the time point of ventilator removal. At $0,5,10$, $15,20,25$, and 30 minutes of warm ischemia, hepatic tissues from the same part of the right lobe of the liver were harvested and snap frozen in liquid nitrogen, and transfer to $-70^{\circ} \mathrm{C}$ freezer for storage (Fig. 1).

\section{Real-time PCR}

Expression of TLR9, TNF- $\alpha$, IRF7, and INF- $\beta$ mRNA was assessed by real-time PCR. Primer pairs: TLR9, forward $5^{\prime}$ - tgcaggagctgaacatgaac- $3^{\prime}$, reward $5^{\prime}$-attggacaggtccacaaagc- $3^{\prime} ;$ TNF- $\alpha$, forward $5^{\prime}$-aaccaaacctgtgccttgtc- $3^{\prime}$, reward $5^{\prime}$-atacacccacacacccact- $3^{\prime} ;$ IRF-7, forward $5^{\prime}$-tctggatgaagctgatgcac- $3^{\prime}$, reward $\quad 5^{\prime}$-agggtccctgagttgtctt- $3^{\prime} ;$ INF- $\beta \quad$ forward $\quad 5^{\prime}$-ctgccctctccatcgactac- $3^{\prime}, \quad$ reward $5^{\prime}$-acccagtgctggagaaattg- $3^{\prime}$, with $\beta$-actin mRNA level as an internal control.

Total tissue RNA was isolated from 0.1 to $0.5 \mathrm{~g}$ of fresh liver tissue by using TREzol (Invitrogen, USA). After reverse transcription by M-MLV RT (M-MLV, Promega, the cDNA products were used for PCR on qRTPCR cycler (Light Cycler, Roche Diagnostics, Mannheim, Germany): $50^{\circ} \mathrm{C} 2 \mathrm{~min}, 95^{\circ} \mathrm{C} 10 \mathrm{~min} ; 95^{\circ} \mathrm{C} 15 \mathrm{sec}$, $60^{\circ} \mathrm{C} 1 \mathrm{~min}, 40$ cycles; $95^{\circ} \mathrm{C} 15 \mathrm{sec}, 60^{\circ} \mathrm{C} 15 \mathrm{sec}, 95^{\circ} \mathrm{C} 15 \mathrm{sec}$.

\section{Western blot}

Cytoplasmic and nuclear proteins were prepared with Subcellular Protein Fractionation Kit (Pierce, USA) and quantified with BCA kit (Pierce, USA). Expression of TLR9, TNF- $\alpha$, IRF7, IFN-ßin $20 \mu$ g of prepared proteins was analyzed by western blot, using primary and secondary antibodies (Santa Cruz, USA). Grey gradient analysis of signal density was done with LabWorks program.

Fig. 1. (A) Real-time PCR shown the mRNA levels of TLR9, IRF7, TNF- $\alpha$, IFN- $\beta$ in liver tissue after warm ischemia at indicated times. ${ }^{*} p<0.05$ : vs 0 min group; ** $p<0.01$ : vs 0 min group. (B) Previous blocking of the TLR9 pathway with $0.1 \mathrm{mg} / \mathrm{kg}$ iCpG prevented the (20 min) ischemia-induced upregulation of the TLR9 pathway involved molecules. $* p<$ 0.05 : vs 0 min group; ${ }^{* *} p<0.01$ : vs control group.

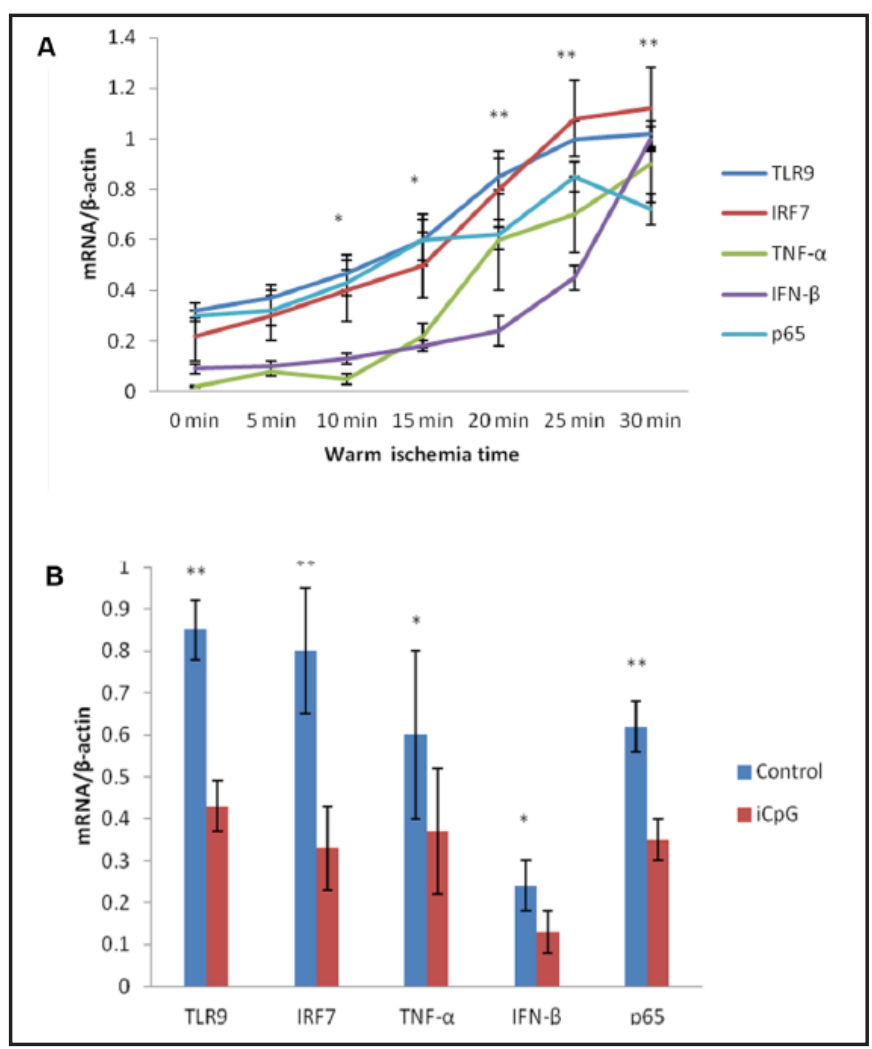




\section{Cellular Physiology Cell Physiol Biochem 2017;41:1547-1554 \begin{tabular}{ll|l} 
and Biochemistry Published online: March 27, 2017 & $\begin{array}{l}\text { (c) 2017 The Author(s). Published by S. Karger AG, Basel } \\
\text { www.karger.com/cpb }\end{array}$
\end{tabular}

Histology and transmission electron microscope examination

Snap frozen liver tissues were submitted for H\&E staining and microscope examination. Electron microscope examination of fresh liver tissues were performed at the Electronic Miscopy Center of our institute after fixation in $2 \%$ paraformaldehyde.

Liver enzyme

Serum aminotransferase (ALT) was determined by ELISA prior to and 20 minutes post ischemia.

Hepatic oxygen tension analysis

Blood samples were collected from pig hepatic artery at the time 0 (before ischemia), 5, 10, 15, 20 min of the warm ischemia (see the Establishment of DCD model and collection of samples). Each $10 \mu \mathrm{l}$ plasma was absorbed into an i-STAT Test Cartridge (CG4+; Abbott Point of Care Inc, Princeton, NJ) for partial pressure of oxygen $\left(\mathrm{PaO}_{2}\right)$ analysis by an i-STAT Portable Blood Gas Analyzer (i-STAT; Abbott Point of Care Inc, Princeton, NJ).

\section{Electron microscopy}

$5 \mathrm{~mm}$ in diameter samples of liver biopsy were fixed in Trump's fixative (postfixed in 1\% osmium tetroxide with sodium cacodylate buffer) for $3 \mathrm{~h}$ at $20{ }^{\circ} \mathrm{C}$, and stained en bloc with $5 \%$ aqueous uranyl acetate. Thick sections $(1 \mu \mathrm{m})$ were then stained with toluidine blue. Thinner sections of 50-70 nm were cut from the stained sample with a LKB8801 ultramicrotome (LKB, Stockholm, Sweden), and stained with uranyl acetate and lead citrate. All samples were then examined and photographed with transmission electron microscope (Philips EM 201).

\section{Statistics}

Data was analyzed with SPSS 16.0 software and presented as mean \pm SD. One-Way ANOVA was used for intergroup comparison, Student-Newman-Keul (sSNK) test for intragroup comparison, and IndependentSample T Test for comparison between two groups.

\section{Results}

Expression of TLR9, IRF7, TNF- $\alpha$, IFN- $\beta$ in liver tissue after warm ischemia

We first assessed the TLR9 pathway molecules at mRNA levels. The real-time PCR data showed that TLR9, IRF7, TNF- $\alpha$, and IFN- $\beta$ mRNA levels in the donor liver increased along prolonged warm ischemia. The TLR9 and IRF7 mRNA both significantly increased after 10 minutes of ischemia, compared to that at baseline $(p<0.0001)$, while increase of TNF- $\alpha$ and IFN- $\beta$ mRNA in the donor organ began to appear at 15 and 20 minutes of ischemia compared to the levels of time 0 , respectively $(p<0.0001)$. In addition, at 15 and 20 minutes of ischemia, increase of TNF- $\alpha$ mRNA in the liver tissue was more prominent than IFN- $\beta$ mRNA did ( $t$ test, ${ }^{*} p<0.05$ vs 0 min group, ${ }^{* *} p<0.01$ vs 0 min group, Fig. 1A). More important, blocking of TLR9 pathway with iCpG remarkably prevented ischemia-induced upregulation of IRF7, TNF- $\alpha$, IFN- $\beta$ mRNA (t test, ${ }^{*} p<0.05$ vs 0 min group, ${ }^{* *} p<0.01$ vs 0 min group, Fig. 1B).

Next, we examined expression of the TLR9 pathway molecules at protein level by western blot. Consistent with our observations with real-time PCR, warm ischemia induced significant expression of TLR9 pathway proteins in a time dependent manner and at the pace of mRNA expression (Fig. 2A). Again, TNF- $\alpha$ and IFN- $\beta$ protein expression was 5 minutes behind TLR9 and IRF7 expression, and elevation of TNF- $\alpha$ protein level was earlier than IFN- $\beta$ protein did ( $\mathrm{t}$ test, ${ }^{*} p<0.05$ vs 0 min group, ${ }^{* *} p<0.01$ vs 0 min group). In line with our results of mRNA studies above, administration of iCpG effectively inhibited overexpression of IRF7, TNF- $\alpha$, IFN- $\beta$ proteins after ischemia (Fig. $2 \mathrm{~B}$ and $2 \mathrm{C}$, ${ }^{* *} p<0.01$ ).

Histological change of the liver tissue of the treated animals were examined as well. Histopathologically, only mild swollen hepatocytes were observed around the central vein prior to ischemia in iCpG-treated samples (Fig. 3A) compared to the iCpG pretreated animals without ischemia (Fig. 3B). However, focal necrosis (universally severe swollen hepatocytes 


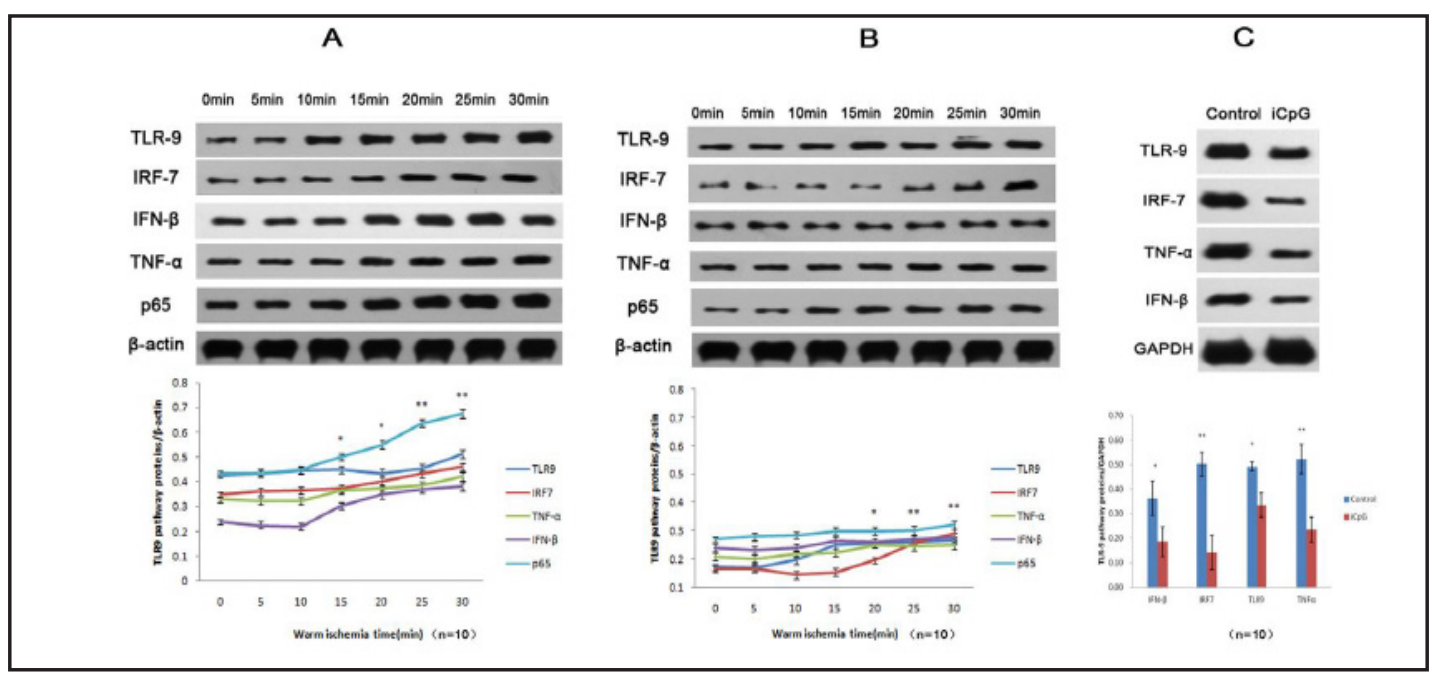

Fig. 2. (A) TLR9 protein expression after 20 min warm ischemia in porcine liver. $\left(^{*} p<0.05\right.$ vs 0 min group, ${ }^{* *} p<0.01$ vs 0 min group). (B) Prevention of over production of TRL9 pathway proteins in vivo by iCpG. (C) In vivo expression of TRL9 pathway proteins in presence or absence of iCpG.

Fig. 3. H\&E stain of liver tissues showed that injection of $\mathrm{iCpG}$ prior to ischemia diminished isechmia-caused liver damage in vivo. (A) Prior to ischemia, control group; (B) Prior to ischemia, iCpG group; (C) Post ischemia, control group; (D) Post ischemia, iCpG group.

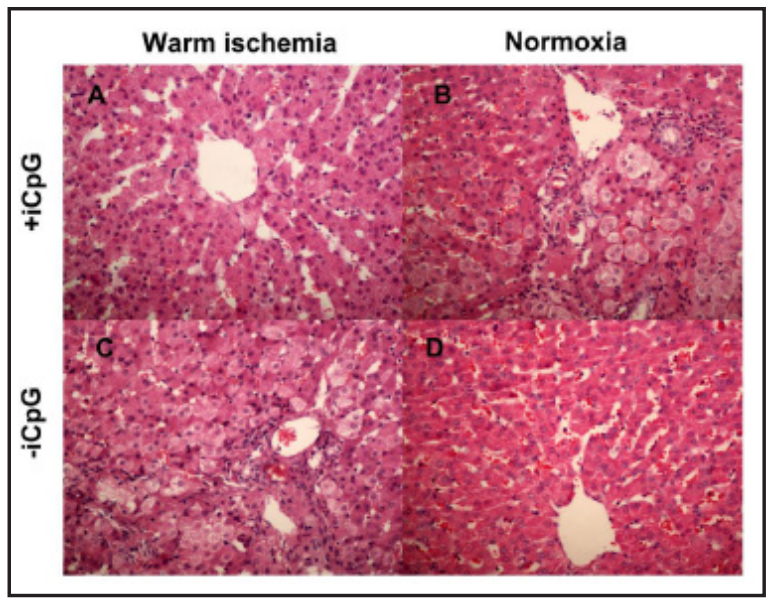

Fig. 4. TEM examination of liver tissue. (A) Prior to ischemia, control group; (B) Prior to ischemia, $\mathrm{iCpG}$ group; (C) Post ischemia, control group; (D) Post ischemia, $\mathrm{iCpG}$ group. $(\times 5000)$.

with enlarged nuclei) were presented in the liver tissue from the animals pretreated with the negative control agent (Fig. 3C) after ischemia, which was not observed in normal controls (Fig. 3D). This result demonstrated that pretreatment with iCPG alleviated ischemia-caused liver damage.

We further observed ultrastructural features of the liver tissue after ischemia with or without iCpG pretreatment. As shown in Figure 4, no difference existed between

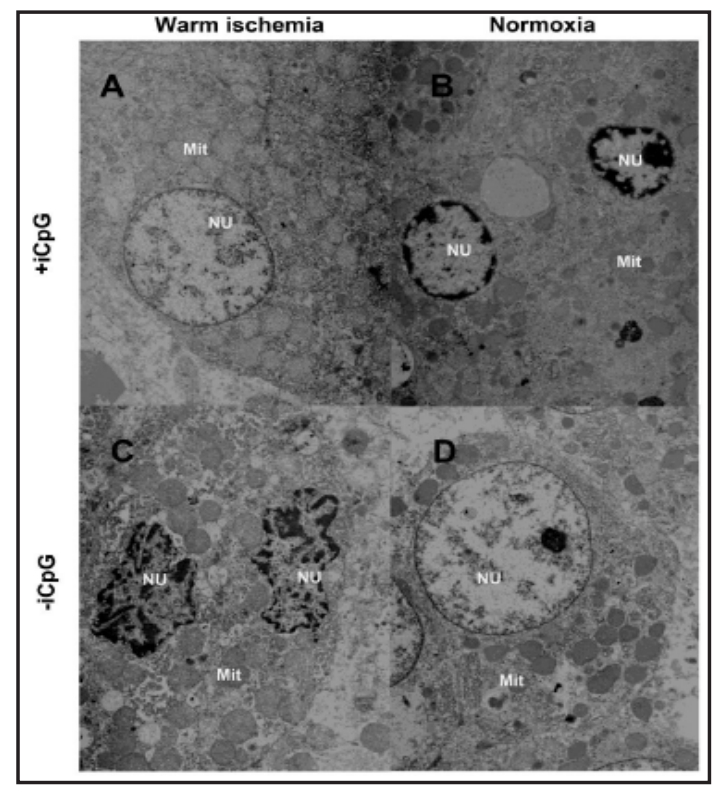

\section{KARGER}




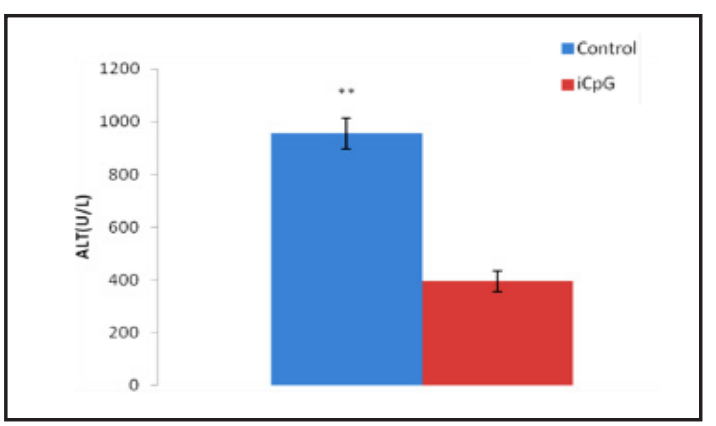

Fig. 5. Serum ALT levels were determined by ELISA after warm ischemia for $20 \mathrm{~min}$ in the animals pre-treated with or without iCpG. ${ }^{*} p<0.05$ : vs 0 min group; $^{* *} p<0.01$ : vs 0 min group.

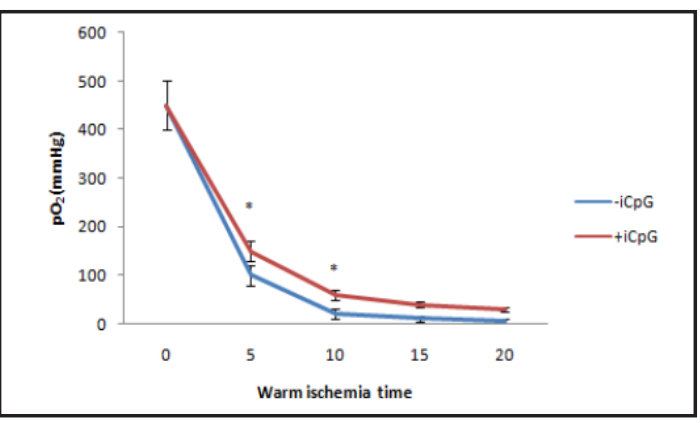

Fig. 6. Hepatic oxygen tension of partial pressure of oxygen $\left(\mathrm{PaO}_{2}\right)$ were analysed in a time course $(0$, 5, 10, 15, $20 \mathrm{~min}$ ) with i-STAT Portable Blood Gas Analyzer during the warm ischemia in iCpG-treated group (red) and non-treatment controls (blue). Each time point was represented with 6-8 independent samples. ${ }^{*} p<0.05$ : vs 0 min group.

ultrastructural characteristics of liver tissues from the control group (Fig. 3D) and those from the iCpG group (Fig. 3B), prior to ischemia. However, 20 minutes after ischemia, severe tissue damage including pyknosis, karyorrhexis, and nuclear/plasma membrane melting were presented in the ischemia alone group (Fig. 4C). In the meantime, only mild shrinkage of nuclei, condensation, and margination of chromatin was presented after pre-treatment with iCpG (Fig. 4A). These results indicated that prohibition of TLR9 pathway with iCpG clearly prevented hepatocyte damage induced by warm ischemia.

In order to evaluate post-ischemia liver function, serum ALT was measured in the animals. The results revealed that ALT elevated 20 minutes after ischemia in both control and iCpG groups ( $p<0.001$, paired t-test), while to a much lower level in iCpG group than that in the control group (Fig. 5, $p<0.01$, t-test). In addition, a hepatic oxygen tension analysis was performed in a time course during warm ischemia, which showed that the partial pressure of oxygen $\left(\mathrm{PaO}_{2}\right)$ levels of iCpG-treated samples at 5 and 10 min after ischemia were obviously higher than that of non-treatment controls. There were no different at 15 and 20 min after warm ischemia (Fig. 6). It suggested that inhibition of TLR9 pathway by iCpG significantly released the hepatic oxygen delivery.

\section{Discussion}

TLRs are important components of the innate and adaptive immune systems and play key role in initiation of immune response [15]. Among the TLRs mediating inflammation, TLR2, TLR4 and TLR9 are related to ischemic injury [16]. Previous studies have demonstrated the involvement of TLR2 and TLR4 in hepatic ischemia [1], but the role of TLR9 in liver ischemia is not clear yet. Our results indicated that warm ischemia activated TLR9 pathways in a time dependent manner and blocking this pathway using iCpG reduced ischemia-induced tissue damage in the liver. Our results suggest that TLR9 signaling pathway is involved in ischemic damage of donor liver.

Activation of TLR9 signals two pathways: the TLR9-NFKB-TNF- $\alpha$ pathway and the TLR9-IRF7-IFN- $\beta$ pathway [17] . In this study, by using porcine liver warm ischemia model, we observed elevated expression of all these signal pathway molecules during the 30-minute warm ischemia period, indicating activation of both pathways.

It is well known that NF- $\mathrm{BB}$ is constantly functional in the cell as a transcription factor protein [18]. In resting cells, NF- $\kappa B$ and I $\kappa B$ form an inactive cytoplasm complex. Upon stimulation by extracellular signals such as activation of TLR receptors, I $\mathrm{B}$ kinase complex (IкB kinase, IKK) phosphorylates IкB, enabling exposure of the nuclear localization sites 
of NF- $\kappa B$ [19]. The free cytoplasmic NF- $\mathrm{B}$ protein rapidly moves to the nucleus, binds to specific $\kappa B$ sequences, and induces transcription of TNF- $\alpha$ and other inflammatory mediators [14]. As the main subunit of NF- $\kappa B$, P65 promotes gene transcription in TLR9 pathways and participates in the subsequent cytokine cascade [20]. From this point of view, activation of p65 reflects activity of NF- $\kappa B$ [21]. In the present study, we found that ischemia induced expression of p65 expression and we believed that hepatic ischemia activated the downstream NF-кB pathway.

Our results also showed that at 15 and 20 min of hepatic ischemia, expression of TNF- $\alpha$ was significantly higher than that of IFN- $\beta$, indicating an earlier and stronger activation of TLR9-NFKB-TNF- $\alpha$ pathway over TLR9-IRF7-IFN- $\beta$ pathway. This finding is consistent with results from previous study [22]. It has been shown that TNF- $\alpha$ is an important mediator of inflammation after acute ischemic injury [23]. TNF- $\alpha$ stimulates expression of tissue factor and leukocyte adhesion molecules, promotes release of interleukin-1, nitric oxide, von Willebrand factor VIII, platelet-activating factor and endothelin, and reduces production of tissue plasminogen activator, thereby reducing the release of plasminogen activator inhibitor-1 [24]. TNF- $\alpha$ also induces xanthine oxidase, cyclooxygenase, and nicotinamide adenine dinucleotide phosphate oxidase. Through these activities, TNF- $\alpha$ irrigates local blood vessels, promotes inflammation, thrombosis and bleeding in these vessels, which contribute to pathogenesis of ischemic injury [25].

Studies have shown that IFN- $\beta$ has not only anti-viral activities but also antiinflammatory functions by reducing intracellular active oxide species [26]. We found that expression of IFN- $\beta$ in the ischemic tissue was increased later along elongation of ischemia time, indicating that IFN- $\beta$ may play a role in late stage of ischemic injury.

Synthetic iCpG is an inhibitory cytosine-guanosine dinucleotide competing with endogenous CpG for binding sites on TLR9 to inhibit TRL9 pathway [12]. Our data form Western blot shown that $\mathrm{iCpG}$ significantly suppressed the downstream molecules of the TLR9 pathway including IRF7 and NF- $\kappa$ B. This could the therapeutic mechanisms of iCpG in the study, reflected by reduction of ischemia-reperfusion cytokines TNF- $\alpha$ and IFN- $\beta$ and histopathological and enzymatic protection effects.

\section{Conclusion}

In summary, warm ischemia could activate TRL9 pathway in a porcine DCD liver transplantation model. Intravenous injection of $\mathrm{iCpG}$ could attenuate warm ischemia caused liver tissue damage by specifically blocking TLR9 pathway.

\section{Acknowledgements}

This work was funded by the project of Special Science Foundation of Ph. D Dissertation of Universities (No. 20132104120018). The authors wish to thank Zhao Ning and Xu Tie for their excellent technical assistance.

\section{Disclosure Statement}

All the authors declare that there is no conflict of interest.

\section{References}

1 He; YMX: The research progress of warm ischemia injury from liver transplantation. Chinese J Hepatobiliary Surg 2001;7:509-510.

-2 Jia JJ, Li JH, Jiang L, Lin BY, Wang L, Su R, Zhou L, Zheng SS: Liver protection strategies in liver transplantation. Hepatobiliary Pancreat Dis Int 2015;14:34-42.

3 Schon MR, Pegg DE: The possibility of resuscitating livers after warm ischemia injury. Transplant Proc 1991;23:2456-2458. 


\section{Cellular Physiology Cell Physiol Biochem 2017;41:1547-1554 \begin{tabular}{l|l} 
and Biochemistry Published online: March 27, 2017 & $\begin{array}{l}\text { (c) } 2017 \text { The Author(s). Published by S. Karger AG, Basel } \\
\text { www.karger.com/cpb }\end{array}$
\end{tabular}}

-4 Banga NR, Homer-Vanniasinkam S, Graham A, Al-Mukhtar A, White SA, Prasad KR: Ischaemic preconditioning in transplantation and major resection of the liver. Br J Surg 2005;92:528-538.

5 Gehrau RC, Mas VR, Dumur CI, Suh JL, Sharma AK, Cathro HP, Maluf DG: Donor Hepatic Steatosis Induce Exacerbated Ischemia-Reperfusion Injury Through Activation of Innate Immune Response Molecular Pathways. Transplantation 2015;99:2523-2533.

6 Xu Z, Yu J, Wu J, Qi F, Wang H, Wang Z, Wang Z: The Effects of Two Anesthetics, Propofol and Sevoflurane, on Liver Ischemia/Reperfusion Injury. Cell Physiol Biochem 2016;38:1631-1642.

7 Hochhauser E, Lahat E, Sultan M, Pappo 0, Waldman M, Sarne Y, Shainberg A, Gutman M, Safran M, Ben Ari Z: Ultra Low Dose Delta 9-Tetrahydrocannabinol Protects Mouse Liver from Ischemia Reperfusion Injury. Cell Physiol Biochem 2015;36:1971-1981.

8 Zhang X, Tan Z, Wang Y, Tang J, Jiang R, Hou J, Zhuo H, Wang X, Ji J, Qin X, Sun B: PTPRO-associated hepatic stellate cell activation plays a critical role in liver fibrosis. Cell Physiol Biochem 2015;35:885-898.

-9 Kaczorowski DJ, Scott MJ, Pibris JP, Afrazi A, Nakao A, Edmonds RD, Kim S, Kwak JH, Liu Y, Fan J, Billiar TR: Mammalian DNA is an endogenous danger signal that stimulates local synthesis and release of complement factor B. Mol Med 2012;18:851-860.

10 Oganesyan G, Saha SK, Guo B, He JQ, Shahangian A, Zarnegar B, Perry A, Cheng G: Critical role of TRAF3 in the Toll-like receptor-dependent and -independent antiviral response. Nature 2006;439:208-211.

11 Thobe BM, Frink M, Hildebrand F, Schwacha MG, Hubbard WJ, Choudhry MA, Chaudry IH: The role of MAPK in Kupffer cell toll-like receptor (TLR) 2-, TLR4-, and TLR9-mediated signaling following traumahemorrhage. J Cell Physiol 2007;210:667-675.

12 Bamboat ZM, Balachandran VP, Ocuin LM, Obaid H, Plitas G, DeMatteo RP: Toll-like receptor 9 inhibition confers protection from liver ischemia-reperfusion injury. Hepatology 2010;51:621-632.

13 Testro AG, Visvanathan K, Skinner N, Markovska V, Crowley P, Angus PW, Gow PJ: Acute allograft rejection in human liver transplant recipients is associated with signaling through toll-like receptor 4. J Gastroenterol Hepatol 2011;26:155-163.

14 Marcu KB, Otero M, Olivotto E, Borzi RM, Goldring MB: NF-kappaB signaling: multiple angles to target OA. Curr Drug Targets 2010;11:599-613.

15 Guiducci C, Gong M, Xu Z, Gill M, Chaussabel D, Meeker T, Chan JH, Wright T, Punaro M, Bolland S, Soumelis V, Banchereau J, Coffman RL, Pascual V, Barrat FJ: TLR recognition of self nucleic acids hampers glucocorticoid activity in lupus. Nature 2010;465:937-941.

16 Roshan MH, Tambo A, Pace NP: The Role of TLR2, TLR4, and TLR9 in the Pathogenesis of Atherosclerosis. Int J Inflam 2016;2016:1532832.

17 Zhang Q, Raoof M, Chen Y, Sumi Y, Sursal T, Junger W, Brohi K, Itagaki K, Hauser CJ: Circulating mitochondrial DAMPs cause inflammatory responses to injury. Nature 2010;464:104-107.

-18 Schumacher M, Cerella C, Reuter S, Dicato M, Diederich M: Anti-inflammatory, pro-apoptotic, and antiproliferative effects of a methanolic neem (Azadirachta indica) leaf extract are mediated via modulation of the nuclear factor-kappaB pathway. Genes Nutr 2011;6:149-160.

19 Ocio EM, Mateos MV, Maiso P, Pandiella A, San-Miguel JF: New drugs in multiple myeloma: mechanisms of action and phase I/II clinical findings. Lancet Oncol 2008;9:1157-1165.

20 Hsieh CY, Hsu MJ, Hsiao G, Wang YH, Huang CW, Chen SW, Jayakumar T, Chiu PT, Chiu YH, Sheu JR: Andrographolide enhances nuclear factor-kappaB subunit p65 Ser536 dephosphorylation through activation of protein phosphatase 2A in vascular smooth muscle cells. J Biol Chem 2011;286:5942-5955.

21 Schoonbroodt S, Piette J: Oxidative stress interference with the nuclear factor-kappa B activation pathways. Biochem Pharmacol 2000;60:1075-1083.

-22 Amantea D, Nappi G, Bernardi G, Bagetta G, Corasaniti MT: Post-ischemic brain damage: pathophysiology and role of inflammatory mediators. FEBS J 2009;276:13-26.

23 Kon ZN, Brown EN, Grant MC, Ozeki T, Burris NS, Collins MJ, Kwon MH, Poston RS: Warm ischemia provokes inflammation and regional hypercoagulability within the heart during off-pump coronary artery bypass: a possible target for serine protease inhibition. Eur J Cardiothorac Surg 2008;33:215-221.

-24 Kannerup AS, Gronbaek H, Funch-Jensen P, Tonnesen E, Jorgensen RL, Mortensen FV: Cytokine changes during warm ischemia and reperfusion of the pig liver with or without preconditioning. Eur Surg Res 2009;42:216-222.

25 Basic Kes V, Simundic AM, Nikolac N, Topic E, Demarin V: Pro-inflammatory and anti-inflammatory cytokines in acute ischemic stroke and their relation to early neurological deficit and stroke outcome. Clin Biochem 2008;41:1330-1334.

-26 Hua LL, Kim MO, Brosnan CF, Lee SC: Modulation of astrocyte inducible nitric oxide synthase and cytokine expression by interferon beta is associated with induction and inhibition of interferon gamma-activated sequence binding activity. J Neurochem 2002;83:1120-1128. 